\begin{tabular}{|c|c|c|c|c|}
\hline JURNAL & \multirow{2}{*}{ VOLUME 3 } & \multirow{2}{*}{ NOMOR 1 } & \multirow{2}{*}{ HALAMAN 105-114 } & $\begin{array}{l}\text { ISSN 2655-8823 }(p) \\
\text { ISSN 2656-1786 (e) }\end{array}$ \\
\hline
\end{tabular}

\title{
PERAN ORANG TUA DALAM MENDAMPINGI ANAK MENGGUNAKAN MEDIA SOSIAL DI TENGAH PANDEMI COVID-19
}

\author{
Sofia Zahara \\ Prodi Ilmu Kesejahteraan Sosial FISIP Univiersitas Padjadjaran \\ E-mail: sofia17003@mail.unpad.ac.id \\ Nandang Mulyana \\ Departemen Kesejahteraan Sosial FISIP Univiersitas Padjadjaran \\ E-mail: mulyananandang@yahoo.com \\ Rudi Saprudin Darwis \\ Departemen Kesejahteraan Sosial FISIP Univiersitas Padjadjaran \\ E-mail: rudi.darwis@unpad.ac.id
}

\begin{abstract}
ABSTRAK
Sejak pertama kali terdeteksi muncul di Kota Wuhan, Tiongkok, pandemi Virus Corona (Covid-19) telah membuat kepanikan dimana-mana, ratusan ribu manusia terinfeksi dan ribuan lainnya meninggal dunia akibat dari pandemi ini. Untuk mengantisipasi dampak pandemi yang lebih besar pemerintah mengkampanyekan kepada masyarakat agar lebih sering berkegiatan di dalam rumah untuk memutus rantai penyebaran virus corona. Situasi tersebut memaksa segala bentuk aktifitas seperti pekerjaan dan pendidikan dilaksanakan di rumah. Anak-anak lebih banyak menghabiskan waktunya di dalam rumah dan menjadi lebih banyak menggunakan gadget dengan media sosial di dalamnya sebagai sarana pembelajaran, berkomunikasi dengan teman dan menghilangkan kebosanan. Penggunaan media sosial di tengah pandemi ini tentunya menimbulkan dampak positif maupun dampak negatif terhadap anak yang menggunakan media sosial. Oleh karena itu pendampingan yang diberikan orang tua sangat diperlukan untuk meminimalisir dampak negatif yang memungkinkan terjadi ketika anak mengakses media sosial di tengah pandemi Covid-19.
\end{abstract}

Kata kunci: covid-19, media sosial, peran orang tua, anak.

\section{PENDAHULUAN}

Virus Corona merupakan bagian dari keluarga virus yang menyerang makhluk hidup, khususnya manusia dan hewan. Coronavirus (COVID-19) merupakan penyakit menular yang penyebabnya yakni coronavirus baru yang diketahui pada akhir tahun 2019 lalu. Sebagian besar gangguan yang dialami oleh kebanyakan individu yang terinfeksi virus Covid-19 ialah gangguan pernapasan mulai dari tingkat ringan hingga berat. Beberapa diantaranya sembuh dengan sendirinya sebab imunnya kuat tanpa menggunakan perawatan tertentu.

Hingga saat ini di Indonesia masih terus berusaha melawan pandemi Covid19, begitupun juga di negara-negara lain. Jumlah kasus virus Corona terus bertambah setiap harinya dengan beberapa melaporkan jumlah kesembuhan, dan jumlah yang meninggal akibat pandemi ini. Upaya penanganan dan pencegahan terus dilakukan demi melawan pandemic ini, dalam upaya menangani pandemi Covid-19 yang semakin luas, social distancing atau pembatasan sosial dilakukan oleh pemerintah selaku pemangku kebijakan demi memutus rantai penyebaran Covid-19, pandemi virus corona Covid-19 telah mengubah banyak kehidupan manusia. Semua orang lebih banyak menghabiskan waktu di dalam rumah. Tidak dipungkiri dengan adanya pandemi Covid-19 berhasil mengubah sebagian besar tatanan kehidupan sosial, termasuk juga kebiasaan dalam berinteraksi. Manusia sebagai makhluk sosial yang seketika diharuskan untuk menyesuaikan diri dengan kebijakan pemerintah yang menginstruksikan untuk melakukan aktivitas di rumah. Dengan begitu, kebijakan tersebut secara langsung 


\begin{tabular}{|c|c|c|c|c|}
\hline JURNAL & \multirow{2}{*}{ VOLUME 3} & \multirow{2}{*}{ NOMOR 1} & HALAMAN 105-114 & $\begin{array}{l}\text { ISSN 2655-8823 }(p) \\
\text { ISSN 2656-1786 }(e)\end{array}$ \\
\hline KOLABORASI RESOLUSI KONFLIK
\end{tabular}

telah mengurangi aktivitas sosial pada setiap individu.

Keluhan selama pemberlakuan kebijakan tersebut banyak dilontarkan oleh sebagian besar individu yang tidak terbiasa melakukan aktivitas di dalam rumah secara terus-menerus. Misal halnya, anak yang rindu bertemu dengan guru dan temantemannya dan begitupun orangtua yang juga rindu bertemu muka dan berkumpul dengan koleganya. Adanya kemajuan teknologi dan informasi yang begitu pesat dapat memberikan dampak positif saat pandemi covid-19 salah satunya media sosial, setiap orang masih bisa terhubung satu sama lain dengan menggunakan media sosial untuk berkomunikasi dengan keluarga, teman, guru dan kolega di tempat kerja, selain itu media sosial telah menjadi salah satu media dalam mengedukasi, dimulai dari banyaknya informasi dan peluang terjadinya interaksi serta arahan untuk menuju pengembangan informasi ke dalam tautan lain. Hal tersebut menandakan bahwa selain keterkaitannya sebagai media hiburan, media sosial dapat dijadikan sebagai alternatif sumber jawaban untuk pertanyaan keseharian, termasuk info dan pertanyaan tentang pandemi Covid-19.

Dengan adanya program working dan learning from home terkait pandemi Covid-19 ini, Indihome mencatat terdapat lonjakan peningkatan pada pengguna layanan internetnya. Lonjakan lain juga terjadi pada penonton harian TV Interaktif Indihome yang meningkat sebesar 3 juta dari 8 juta ke 11 juta pengguna. Pembatasan aktivitas di luar membuat Indihome mengalami peningkatan tersebut. Peningkatan data layanan video streaming Youtube dan MAXstream, Telkomsel mencatat ada lonjakan peningkatan payload sebesar 17 persen. Facebook juga memaparkan hasil temuanya sendiri. Secara umum, Facebook mengumumkan bahwa adanya peningkatan jumlah pesan yang diakses melalui platformnya sebanyak kurang lebih dari $50 \%$. Jumlah ini merupakan gabungan dari
Facebook Messenger, WhatsApp dan Instagram.

Kebanyakan orang menghabiskan waktunya untuk bermain media sosial, seperti Facebook, Youtube, Instagram hingga Twitter. Terlepas dari hal positif dari penggunaan media sosial tentunya akan membawa dampak negatif kepada penggunanya dalam situasi pandemi Covid-19, seperti dapat menyebabkan banyak masalah saat ini banyak informasi yang salah kaprah mengenai pandemi COVID-19, anak pasti akan mudah menyerap berbagai informasi yang tidak dapat dipertanggungjawabkan kredibilitasnya selain itu kekerasan seksual melalui media sosial terus mengalami peningkatan dalam beberapa tahun terakhir. Bahkan, trennya semakin marak di masa pandemi Covid-19 yang memungkinkan komunikasi lebih sering dilakukan secara virtual atau di dunia media sosial. Data tersebut disampaikan oleh Komisioner Komisi Nasional Antikekerasan Terhadap Perempuan Alimatul Qibtiyah pada Webinar "Menciptakan dan Memelihara Kampus Nirkekerasan" yang diselenggarakan Pusat Kajian dan Pengembangan Kependudukan, Peranan Wanita/Gender, dan Perlindungan Anak (PKPWA) LPPM Universitas Pendidikan Indonesia, Senin 18 Mei 2020.

Dilansir dari sumber berita online dari Inggris, Reuters, aktivis dari Thomson Reuters Foundation menyebutkan bahwa kemungkinan perdagangan cybersex saat pandemic corona virus ini berupa pelecehan seksual online menargetkan lebih banyak anak-anak di Asia Tenggara. Kasus yang terjadi di Philippines saat ini adalah terjadi perdangan pelecehan seksual secara live stream. Live stream yang dimaksud disini mengacu kepada konten yang disiarkan secara langsung melalui media internet berupa video dan audio. Jutaan anak-anak dapat mengalami resiko bahata yang lebih besar karena kehidupan mereka semakin online saat dikunci dalam pandemi COVID-19, UNICEF dan rekannya mengatakan Pandemi virus 


\begin{tabular}{|c|c|c|c|c|}
\hline JURNAL & \multirow{2}{*}{ VOLUME 3} & \multirow{2}{*}{ NOMOR 1} & HALAMAN 105-114 & $\begin{array}{l}\text { ISSN 2655-8823 }(p) \\
\text { ISSN 2656-1786 }(e)\end{array}$ \\
\hline KOLABORASI RESOLUSI KONFLIK
\end{tabular}

corona telah menyebabkan peningkatan waktu layar yang belum pernah terjadi sebelumnya, Menurut Direktur Eksekutif Kemitraan Global untuk Mengakhiri Kekerasan Dr. Howard Taylor "Penutupan sekolah dan langkah-langkah pengendalian yang ketat berarti semakin banyak keluarga yang mengandalkan teknologi dan solusi digital untuk membuat anakanak tetap belajar, terhibur dan terhubung dengan dunia luar, tetapi tidak semua anak memiliki pengetahuan, keterampilan, dan sumber daya yang diperlukan untuk menjaga diri mereka tetap aman saat online."

Lebih dari 1,5 miliar anak-anak dan remaja dipengaruhi oleh penutupan sekolah di seluruh dunia. Banyak dari siswa-siswi pada saat sekarang ini mengambil kelas dan juga bersosialisasi secara online. Menghabiskan lebih banyak waktu di platform virtual dapat membuat anak-anak rentan terhadap eksploitasi dan perawatan seksual online, karena predator ingin mengeksploitasi pandemi Covid-19. Kurangnya kontak tatap muka dengan teman dan mitra dapat menyebabkan pengambilan risiko yang meningkat seperti mengirim gambar seksual, sementara waktu online yang meningkat dan tidak terstruktur dapat memaparkan anak-anak ke konten yang berpotensi berbahaya dan kekerasan serta risiko yang lebih besar dari penindasan cyber.

Menurut Direktur Eksekutif UNICEF Henrietta Fore (2020) kehidupan jutaan anak dalam pandemi Covid-19 sementara menyusut menjadi lebih banyak menghabiskan waktu di rumah dan internet. Dalam hal ini maka perlunya seluruh pihak-pihak tertentu untuk membantu mereka menavigasi realitas baru ini dengan ikut mengamankan anakanak dalam penggunaan internet agar anak-anak dapat terlindungi dari bahaya internet itu sendiri. UNICEF bersama dengan para mitranya, Kemitraan Global untuk Mengakhiri Kekerasan terhadap Anak-anak, International Telecommunication Union (ITU),
Organisasi Pendidikan, Ilmu Pengetahuan dan Kebudayaan PBB (UNESCO), Kantor PBB untuk Narkoba dan Kejahatan (UNODC), Aliansi Global WePROTECT, Aliansi Kesehatan Dunia, Organisasi Kesehatan Dunia (WHO), dan World Childhood Foundation USA (Childhood USA), merilis catatan teknis baru yang ditujukan untuk mendesak pemerintah, industri TIK, pendidik dan orang tua agar waspada, mengambil langkah-langkah mendesak untuk mengurangi risiko potensial, dan memastikan pengalaman online anak-anak aman dan positif selama COVID-19. Penelitian Pratiwi \& Jannah (2017) menunjukkan bahwa perlu cara yang bijak dalam pengawasan penggunaan media sosial oleh orang tua, karena cara pengawasan yang otoritatif tidak dapat menghindarkan dampak negatif penggunaan media sosial.

Penggunaan teknologi menjadi merupakan suatu pilihan yang tidak dapat dihindari dalam pendidikan. Yang penting adalah mengarahkan produk teknologi agar dapat dimanfaatkan dengan baik untuk kepentingan pengembangan pendidikan (Gunawan, 2016). Adanya fenomena dampak negatif penggunaan media sosial pada anak di tengah pandemi Covid19 ini maka dibutuhkan peran orang tua dalam mendampingi anak saat menggunakan media sosial, dengan membatasi dan mempengaruhi perilaku anak dalam berinteraksi dengan orang lain (Le Poire dalam Kusumadewi, 2010). Hal ini dapat meminimalisir dampak negatif yang terjadi kepada anak ketika anak mengakses media sosial, dengan adanya peran orang tua di dalamnya anak merasa terlindungi dan terkontrol.

\section{METODE PENELITIAN}

Metode yang digunakan dalam penelitian ini adalah studi literatur. Data yang tersaji diperoleh adalah data sekunder yang diperoleh dari berbagai studi pustaka yang diperoleh pada buku, skripsi, berita, dan jurnal yang menjelaskan mengenai peran orang tua dalam mendampingi anak 
bermedia sosial di tengah pandemi Covid19.

\section{HASIL DAN PEMBAHASAN}

Orang tua yaitu terdiri dari ayah dan ibu memiliki peran besar dan krusial dalam proses membimbing dan mendampingi anak baik dalam pendidikan formal maupun non-formal. Peran orang tua itu sendiri dapat mempengaruhi perkembangan anak dalam aspek kognitif, afektif, dan psikomotor. Menurut Lestari (2012:153) peran orang tua merupakan cara yang digunakan oleh orang tua berkaitan dengan pandangan mengenai tugas yang harus dijalankan dalam mengasuh anak. Orang tua memberikan pendidikan mulai dari kecil kepada anak. Berikut peranan orang tua terhadap anak (Amin, 2017):

a. Orang tua sebagai pendidik

Orang tua mempersiapkan pendidikan bagi anak-anaknya sejak dini, dengan memulai tahapan dalam mendidik dan membesarkan anak-anak, karena masa itulah masa pertumbuhan anak yang paling penting dalam membentuk pribadi dan garis-garis besar corak kepribadian anak dan masa kanak-kanak hingga dewasa (Wahidin, 2012). Peranan orang tua sebagai pendidik bagi anakanaknya, orang tua mengambil peran sebagai pendidik yaitu mengajarkan tentang mana hal yang baik, dan mana hal yang buruk kepada anak. Orang tua sebagai pendidik dalam hal ini yaitu sebagai guru ketika anak anaknya dirumah. Orang tua tidak bisa melimpahkan tanggung jawab ini sepenuhnya kepada guru disekolah, harus ada kerja sama yang bersinergi antara orang tua siswa dengan pihak sekolah dalam menumbuhkan dan mensukseskan pendidikan anak. b. Orang tua sebagai pelindung

Orang tua merupakan pelindung bagi anak-anaknya. Orang tua adalah sosok pelindung yang menurut anak yang paling aman (Ardiansyah \& Arda, 2020). Dalam perannya ini, orang tua diibaratkan sebagai tameng atau pelindung yang selalu siap sedia kapanpun untuk melindungi anak-anaknya dari berbagai hal-hal yang tidak baik. Jenis perlindungan yang bisa dan biasa diberikan orang tua kepada anak-anaknya terdiri atas perlindungan kesehatan, perlindungan keamanan, dan perlindungan jaminan kesejahteraan bagi anak anaknya. Perlindungan yang diberikan oleh orang tua kepada anak-anaknya tersebut bersifat naluriah.

c. Orang Tua Sebagai Pengarah

Peran orang tua yang ini tidak berbeda dengan peran orang tua terhadap anak sebagai pendidik. Dalam perannya kali ini, tugas orang tua ialah mengarahkan anakanaknya pada hal-hal baik yang dapat berguna bagi kehidupannya. Peran ini sangat dituntut berlebih ketika anak sudah menginjak masa remaja. Mereka, anak-anak remaja, dikenal memiliki kelabilan emosi. Pada masa ini mereka menjalani tahap memilih serta mencari hal yang dianggap benar. Tidak jarang mereka menyerap, mengambil semua yang ditemuinya di jalan dan tugas orang tuanyalah yang membantu mengarahkan. Orang tua sebagai tenaga pengarah yaitu orang tua yang selalu mengarahkan anaknya ke hal-hal yang positif. Karena pengarahan dari orang tua itu sangat penting bagi anakanaknya.

d. Peran orang tua sebagai penasehat

Peran orang tua terhadap anak yang saat ini boleh dikatakan 


\begin{tabular}{|c|c|c|c|c|}
\hline JURNAL & \multirow{2}{*}{ VOLUME 3} & \multirow{2}{*}{ NOMOR 1} & HALAMAN 105-114 & $\begin{array}{l}\text { ISSN 2655-8823 }(p) \\
\text { ISSN 2656-1786 }(e)\end{array}$ \\
\hline KOLABORASI RESOLUSI KONFLIK
\end{tabular}

sebagai peran lanjutan dari peran pendidik dan tenaga pengarah. Memberi nasihat adalah sesuatu yang sangat identik dengan orang tua. Namun, dalam menjalankan perannya ini, tidak sedikit orang tua yang menemui hambatan sehingga cukup kesulitan. Pada dasarnya, tidak ada manusia yang suka dinasehati, mereka akan merasa apabila mendapat nasehat membuat dirinya terlihat bodoh, terlihat tidak berguna dan salah. Oleh karena itu, sebagai orang tua juga dituntut pintar ketika akan memberinya nasihat, pastikan caranya berbeda dan tidak berkesan menggurui. Anak-anak sudah cukup pusing dengan tuntutan dari gurunya di sekolah. Mereka juga cukup pusing dengan nasihat guruguru disekolah. Untuk itu, bisa mencoba cara lain untuk menasehati mereka, caranya bisa bermacam-macam tergantung kebutuhan anak-anak, yang jelas berbicara dari hati kehati adalah cara yang paling baik. Orang tua selalu menasehati anaknya karena apapun yang dilakukan oleh anak itu juga akan menyangkut paut kan kepada orang tuanya.

e. Peran Orang Tua Sebagai Penanggung Jawab

Peran orang tua sebagai penanggung jawab anak adalah bentuk perlindungan kepada anakanaknya. Dalam kehidupan, tidak semua nya berjalan dengan baik sesuai yang diharapkan, termasuk berkenaan dengan anak-anak dalam perjalanannya menjadi dewasa.

Berdasarkan penjelasan diatas mengenai peran orang tua kita pahami bahwa peran orang tua sanagatlah penting untuk mengajarkan anak berperilaku baik dalam kehidupannya dan melindungi anak kepada hal-hal yang tidak baik. Peran orang tua merupakan cara yang digunakan oleh orang tua atau keluarga dalam menjalankan tugas dalam mengasuh mendidik, melindungi, mengarahkan dan mempersiapkan anak dalam keidupan bermasyarakat yang lebih baik. Peran orang tua sangat penting dalam perkembangan anak baik dari aspek kognitif, afektif dan psikomotor.

\section{Anak Dengan Dampak Media Sosial Di Tengah Pandemi Covid-19}

Menurut John Locke (dalam Gunarsa, 1992) anak merupakan pribadi yang masih bersih dan peka terhadap rangsanganrangsangan yang berasal dari lingkungan. Augustinus (dalam Suryabrata, 2000), yang dipandang sebagai peletak dasar permulaan psikologi anak, mengatakan bahwa anak tidaklah sama dengan orang dewasa, anak mempunyai kecenderungan untuk menyimpang dari hukum dan ketertiban yang disebabkan oleh keterbatasan pengetahuan dan pengertian terhadap realita kehidupan sehingga dalam konklusinya mereka cenderung mencontoh hal-hal yang diterimanya termasuk aturanaturan yang sifatnya paksaan.

Merujuk kepada teori tersebut sangatlah penting peran pendampingan orang tua dalam mendampingi anak ketika mengakses media sosial, mengingat sesuai teori tersebut usia anak cenderung menyimpang dari hukum dan ketertiban hal tersebut dikarenakan minimnya pengetahuan dan realita kehidupan. Dalam situasi Pandemi Covid-19 anak dihadapkan lebih sering untuk menggunakan media sosial didalam penggunaan media sosial tersebut sangatlah berpotensi untuk anak melakukan atau mendapatkan hal negatif. Menurut Nahar (2020, dalam AKURAT.CO), anak-anak yang tidak memiliki niat untuk melakukan hal negatif, dalam internet mereka bisa ditawarkan dengan pilihan yang mengarahkan mereka pada perbuatan negatif. Maka dari itu perlunya peran seluruh masyarakat khususnya peran keluarga untuk menghindari masalah baru tersebut ketika anak-anak lama menghabiskan waktu 
berada di rumah, selain menghindarkan anak dari konten negatif di media sosial, orangtua dapat sebisa mungkin mampu membuat aktivitas belajar dari rumah (BdR) menjadi lebih menyenangkan, dan membantu mengajarkan anak-anak menyelesaikan tugas belajar.

Ketika anak mendapatkan tugas belajar yang berat, maka orang tua dapat membantu mengajarkan anak untuk menyelesaikan tugas tersebut, dengan tidak mengerjakan keseluruhan yang dapat membuat anak tidak mendapatkan ilmu pembelajaran selama BdR. Oleh karena itu harus adanya komunikasi positif dan kesepakatan yang disusun antara orangtua dengan anak. Masyarakat diimbau untuk bekerja, belajar, dan beribadah di rumah selama wabah korona covid-19. Proses belajar untuk keperluan sekolah anak pun setiap harinya menggunakan internet, sementara jika tidak didampingi orang tua dengan baik setidaknya akan memunculkan macam-macam dampak negatif yang bisa di dapatkan anak saat tidak tepat dalam mengakses internet atau media sosial, menurut UNICEF Indonesia, Astrid Gonzaa Dionsio (2020) ada beberapa dampak negatif dari penggunaan internet atau media sosial ditengah pandemic Covid-19 anatara lain:

1. Self abuse atau penyalahgunaan diri

2. Terpapar dengan kekerasan, termasuk kekerasan seksual, cyberbullying

3. Eksploitasi pada anak

Cara yang paling tepat dalam mendampingi anak mengakses media sosial ialah dengan komunikasi yang terbuka antara orang tua dengan anaknya, dalam mendampingi anak mengakses media sosial sebagai orang tua sebaiknya melakukan pendekatan seperti halnya menjadi seorang teman bagi anaknya dengan begitu anak akan merasa lebih terbuka dan tidak takut untuk bercerita tentang permasalahan di media sosialnya. Selain itu, buat kesepakatan waktu penggunaan internet dan apa saja situs yang boleh dan tidak boleh diakses oleh anak.

Media sosial sebagai produk kemajuan teknologi dan informasi selain memudahkan komunikasi dengan orang lain rupanya memberikan manfaat lainnya. Manfaat media sosial tersebut dapat dirasakan dalam kehidupan sehari-hari selama pandemi. Intensitas penggunaan media sosial di seluruh dunia, termasuk Indonesia begitu meningkat di masa pandemi COVID-19. Media sosial menjadi komoditas penting untuk membantu para pekerja yang harus bekerja dari rumah dan juga anak-anak yang mengikuti program Belajar Di Rumah (BdR).

Namun masyarakat, khususnya para orangtua harus perlu mewaspadai ancaman dibalik ketergantungan anak-anak dengan internet saat masa karantina yang berlansung saat ini sampai waktu yang belum bisa ditentukan. Para orangtua atau pengasuh anak harus semakin aktif melakukan pendampingan dan membangun komunikasi positif dengan anak saat menggunakan internet, baik selama proses BdR, maupun di luar proses BdR. Deputi Bidang Perlindungan Anak Kementerian Pemberdayaan Perempuan dan Perlindungan Anak (KemenPPPA), Nahar, mengatakan kalau penggunaan internet, selain memiliki manfaat juga memiliki dampak negatif, seperti konten pornografi, kejahatan seksual dan eksploitasi terhadap anak, dan grooming alais pencabulan melalui media sosial.

Setiap saat media terus menyampaikan informasi terkait penyebaran pandemi virus Covid-19 yang semakin meluas, dengan korban yang terus bertambah. Kemudian beredarnya banyak infomasi yang salah, narasi yang semakin dapat menimbulkan kegelisahan dan ketakutan di tengah masyarakat. Sehingga, keadaan terasa semakin mencekam dan menakutkan. Jika kegelisahan dan kepanikan terus terjadi, maka yang paling rentan merasakan dampaknya adalah anakanak. Akibatnya bagi anak tidak hanya saat ini, namun jika anak telah mengalami 
stres akibat kondisi tersebut maka akan menimbulkan dampak jangka panjang. Bisa saja mereka akan mengalami gangguan dalam proses tumbuhkembangnya. Terutama pada perkembangan mental dan psikis anak. Oleh karena itu, pada situasi saat ini anak harus mendapatkan perlakukan atau perhatian khusus dari orang terdekat terutama orangtua.

\section{Peran Orang Tua Dalam Mendampingi Anak Saat Menggunakan Media Sosial Di Tengah Pandemi Covid-19}

Berbicara tentang peran orang tua, tidak terlepas dari keluarga. Menurut Lestari, (2012) menyatakan bahwa keluarga dilihat dari fungsinya yakni memiliki tugas dan fungsi perawatan, dukungan emosi dan materi, serta pemenuhan peranan tertentu. Sejalan dengan hal tersebut, Menurut Muchtar (dalam Lutfatutatifah et al., 2015) mengugkapkan bahwa keluarga merupakan bagian terpenting dari unit masyarakat. Keluarga memiliki peran penting dalam merawat, mendidik, melindungi dan mengasuh anak. Orangtua yang baik di masa lampau berperan mengenalkan anak dengan budaya yang lebih luas. Akan tetapi di era globalisasi ini, orangtua berperan juga untuk melindungi anak dari budaya konsumtif, hidup bebas, egosentris yang merupakan efek negatif dari globalisasi. Orangtua dapat melindungi anaknya dari budayabudaya negatif tersebut dengan mengajarkan nilai-nilai yang dianggap baik menurut orangtua (Pipher, 1996 dalam Victoriana, 2012). Kemunculan internet merupakan salah satu perkembangan masuknya globalisasi dengan adanya media sosial yang membuat masyarakat didunia terkoneksi satu sama lain dalam lingkungan global yang tanpa batas.

Di tengah pandemi Covid-19 ini media sosial memiliki pengaruh positf dan tentunya membawa pengaruh negatif pada anak-anak salah satu dari pengaruh positif ialah anak dapat mudah untuk terhubung dengan teman-temannya, sebagai sarana untuk pendidikan anak, dan sarana hiburan anak sedangkan penggunaan media sosial dapat membawa pengaruh negatif terhadap setiap penggunanya khususnya bagi anakanak, salah satunya cyberbullying, pornografi, cenderung lupa waktu, pergaulan bebas, kecemasaan yang timbul akibat berita pandemi Covid-19 yang membuat ketakutan pada anak, selain itu anak akan mudah depresi, anak yang menggunakan media sosial tanpa peranan orang tua yang mendampingi akan sangat berpotensi untuk melakukan hal-hal negatif ataupun mendapatkan perlakuan negatif dari penggunaan media sosial itu sendiri.

Untuk meminimalisir dampak negatif tersebut tentunya diperlukan peran orangtua sebagai figur, monitor dan pengendali dalam penggunaan media sosial secara bijak dan bertanggung jawab. Berdasarkan konsep dari Suerlin (2013:124) mengenai peran orang tua di dalam keluarga terutama terhadap anak. Konsep tersebut terdiri dari: peran orang tua sebagai pendidik, peran orang tua sebagai pelindung, peran orang tua sebagai pengarah, peran orang tua sebagai penasehat, peran orang tua sebagai penanggung jawab.

Maka peran orang tua dalam mendampingi anak bermedia sosial dapat dilihat ketika mereka mampu memenuhi indikator-indikator peranan dalam mendampingi anak bermedia sosial, indikator pertama adalah peranan orang tua dalam mendidik anak bermedia social. Peran orang tua dalam mendidik ialah mengajarkan anak tentang sopan santun, tentang bagaimana seharusnya anak bersikap baik terhadap orang lain dan dapat mengembangkan kemampuannya. Dalam bentuk pendampingan kepada anak yang menggunakan media sosial ialah, orang tua mengajarkan anak dalam bersikap baik di media sosia, orang tua mengajarkan anak untuk mengambil halhal positif di media sosial untuk 


\begin{tabular}{|c|c|c|c|c|}
\hline JURNAL & \multirow{2}{*}{ VOLUME 3 } & \multirow{2}{*}{ NOMOR 1 } & \multirow{2}{*}{ HALAMAN 105-114 } & $\begin{array}{l}\text { ISSN 2655-8823 }(p) \\
\text { ISSN 2656-1786 (e) }\end{array}$ \\
\hline KOLABORASI RESOLUSI KONFLIK & VAM \\
\hline
\end{tabular}

pengembangan anak, orang tua mengajarkan anak untuk mengakses media sosial yang positif.

Indikator kedua adalah peranan orang tua sebagai pelindung, orang tua adalah pelindung anak-anaknya, Dalam bentuk pendampingan kepada anak yang menggunakan media sosial ialah, orang tua siap sedia kapanpun untuk melindungi anak-anaknya dari berbagai hal yang tidak baik, seperti orang tua mengontrol waktu penggunaan media sosial, orang tua mengontrol media sosial anak, orang tua mengontrol penggunaan media sosial anak dan tentunya orang tua meluangkan waktu untuk berdiskusi bersama anak mengenai media sosial anak.

Indikator ketiga adalah peranan orang tua sebagai pengarah, orang tua sebagai pengarah untuk anak-anaknya tentunya mengarahkan anak kepada hal-hal yang baik, anak sangat butuh penagarahan orang tua untuk membuat anak lebih terkontrol. Dalam bentuk pendampingan kepada anak yang menggunakan media sosial ialah, orang tua orang tua mengarahkan anak dalam bertutur kata yang baik di media sosial, orang tua mengarahkan anak dalam menjaga nama baik diri dan keluarga di media sosial, orang tua mengarahkan anak untuk tidak mengikuti hal-hal yang tidak baik di media sosial.

Indikator keempat dalah peranan orang tua sebagai pemberi nasehat, orang tua diharapkan dapat memberikan arahanarahan yang baik terhadap penggunaan media sosial bagi anak. Dalam bentuk pendampingan kepada anak yang menggunakan media sosial ialah, orang tua memberikan masukan tentang manfaat penggunaan media sosial yang baik, orang tua memberitahukan positif" postingan, seperti postingan di medsos tentang hal yang memotivasi dari keagamaan maupun ilmu pengetahuan, orang tua memberikan saran postingan yang baik di media sosial anaknya.

Indikator kelima adalah peranan orang tua sebagai penganggung jawab, orang tua bertanggung jawab untuk membimbing anak-anaknya dalam mencapai tahapan tertentu yang dapat mengantarkan anak untuk siap dalam kehidupan bermasyarakat. Dalam bentuk pendampingan kepada anak yang menggunakan media sosial ialah, orang tua bertanggung jawab untuk memperbaiki ketika anak melakukan atau mendapatkan perlakuan yang tidak baik di media sosial, orang tua beratnggung jawab untuk memastikan anak tidak melanggar normanorma dalam penggunaan media sosial, orang tua bertanggung jawab untuk memberikan pengetahuan mengenai media sosial kepada anak sebelum menggunakan media sosial.

\section{KESIMPULAN}

Penggunaan media sosial saat pandemi Covid-19 saat ini memiliki peningkatan yang signifikan dikarenakan kebiasaan baru masyarakat yang lebih sering berada di dalam rumah, tentunya hal ini merupakan bentuk upaya dari pencegahan penyebaran virus Covid-19 yang semakin meluas. Media sosial menjadi suatu sarana untuk pembelajaran anak-anak, membantu komunikasi anatara sesama dan menjadi suatu hiburan di tengah pandemi Covid-19 ini. Dengan adanya panemi ini para orangtua bisa lebih mengexplorasi satu bentuk pendidikan bagi anaknya khususnya mengetahui lebih banyak tentang detail dari pandemi virus Corona19 melalui fasilitas media sosial, hal ini dilakukan dengan pendampingan sehingga ketika anak mengakses media sosial dan mendapatkan berita tidak akurat di media sosial orang tua dapat mengkontrol tersebut dengan pengetahuan yang didapatnya. Saat ini media sosial merupakan cara lain bagi anak untuk berinteraksi dengan teman-teman, sarana hiburan dan menjadi saranan pembelajaran di tengah pandemi Covid-19 dengan begitu anak akan lebih sering menggunakan media sosial, dari penggunaan media sosial pada anak tersebut tentunya akan membawa dampak negatif ketika tidak adanya peran orang tua di dalamnya dalam 


\begin{tabular}{|c|c|c|c|c|}
\hline JURNAL & \multirow{2}{*}{ VOLUME 3 } & \multirow{2}{*}{ NOMOR 1 } & HALAMAN 105-114 & $\begin{array}{l}\text { ISSN 2655-8823 }(p) \\
\text { ISSN 2656-1786 (e) }\end{array}$ \\
\hline
\end{tabular}

mendampingi anak dalam penggunaan media sosial salah satunya kecemasan yang didapat anak mengenai berita yang tidak akurat di media sosial, peningkatan perilaku cyberbullying, cybersex, exploitasi membuka situs pornografi. Untuk meminimalisir dampak negatif tersebut perlunya peran orang tua dalam mendampingi anak di tengah pandemi Covid-19 sehingga anak akan lebih terlindungi dan terkontrol.

\section{DAFTAR PUSTAKA}

Amin, Haerul. (2017). Peran Orang Tua Remaja (Studi Kasus Di Lorong Jambu Peran Orang Tua Dalam Menanggulangi Kenakalan (Studi Kasus Di Lorong Jambu Kelurahan Anggoeya Ya Kecamatan Poasia Kota Kendari Kenakalan Kelurahan Kota Kendari). Thesis, IAIN KENDARI. melalui http://digilib.iainkendari.ac.id/i d/eprint/762

Ardiansyah \& Arda. (2020). Peran Orang Tua dalam Proses Belajar Anak di Masa Pandemi Covid-19 dalam Menumbuhkan Sikap Ilmiah (Studi Kasus Pada Siswa Usia 10-12 Tahun pada Mata Pelajaran IPA). Musawa: Journal for Gender Studies, Vol 12 (1)

BKKBN. (2020) MENDAMPINGI ANAK SELAMA COVID-19: Bkkbn. Retrieved Juni 11, 2020, melalui http://sumbar.bkkbn.go.id/men dampingi-anak-selama-covid-19/

Gunarsa, Singgih D. (1992). Psikologi Perkembangan, Jakarta: BPK-Gunung Mulia.

Gunawan, Agus. (2016). Pemanfaatan Teknologi Informasi dan Komunikasi Melalui Penggunaan Media Pendidikan dalam Pembelajaran IPS SD. Pedagogi Jurnal Penelitian Pendidikan, Volume $03 \quad$ No 02 November 2016. DOI: https://doi.org/10.25134/pedagog i.v3i2.1162

Hyoscyamina, D. E. (2011). Peran Keluarga Dalam Membangun Karakter Anak. Jurnal Psikologi, 10(2), 144-
152. https://doi.org/https://doi.org/10.1 4710/jpu.10.2.144-152

Kusumadewi, N. O. (2010) Pengalaman Komunikasi Orangtua dan Remaja dalam Memahami Dampak Penggunaan Situs Jejaring Sosial Facebook. Undergraduate thesis, Diponegoro University.

Lestari, Sri. (2012). Psikologi Keluarga. Jakarta: Kencana Preanada Media Group

Lutfatutatifah, Adriany dkk. (2015). Pola Asuh Orang Tua Anak Usia Dini Di Kampung Adat Benda Kerep Kota Cirebon, Jurnal Pendidikan Serantau Vol 1(1)

Pratiwi, W.R. \& Jannah, Sy.R. (2017). Pengawasan Orang Tua dengan Dampak Penggunaan Media Sosial Pada Remaja. Jurnal Ilmiah Mahasiswa Fakultas Keperawatan, Vol. 2 (3).

Suryabrata, Sumadi, 2000. Pengembangan Alat Ukur Psikologis. Yogyakarta:

Unicef. (2020) Children at increased risk of harm online during global COVID19 pandemic. Unicef. Retrieved April 14 , 2020, from https://www.unicef.org/pressreleases/children-increased-risk-harmonline-during-global-covid-19pandemic

Victoriana, Evany. (2012). Peran Orangtua dalam Pengembangan Kepribadian Anak di Era Globalisasi. Melalui http://repository.maranatha.ed u/id/eprint/4465. Diakses tanggal 20 Agustus 2017.

Wahidin, Unang. (2012). Peran Strategis Keluarga Dalam Pendidikan Anak. Edukasi Islami: Jurnal Pendidikan Islam Vol 1 (2).

\section{Sumber lainnya:}

"Pandemi COVID-19, Orangtua Wajib Dampingi Penggunaan Internet Pada Anak Saat Belajar dari Rumah": AKURAT.CO. Retrieved Mei 11, 2020, melalui https://akurat.co/gayahidup/id- 


\begin{tabular}{|c|c|c|c|c|}
\hline JURNAL & \multirow{2}{*}{ VOLUME 3} & \multirow{2}{*}{ NOMOR 1} & HALAMAN 105-114 & $\begin{array}{c}\text { ISSN 2655-8823 }(p) \\
\text { ISSN 2656-1786 }(e)\end{array}$ \\
\hline
\end{tabular}

1112612-read-pandemi-covid19orangtua-wajib-dampingi-penggunaaninternet-pada-anak-saat-belajar-darirumah

"Pengguna Internet Kala WFH Corona Meningkat 40 Persen di RI”, CNN Indonesia. Retrieved April 9,2020, from https://www.cnnindonesia.com/t eknologi/20200408124947-213491594/pengguna-internet-kala-wfhcorona-meningkat-40-persen-di-ri

"Peran dan Fungsi Media Sosial Saat Pandemi Covid-19”: Kompasiana. Retrieved Mei 22,2020, from

https://www.kompasiana.com/lutfitongar/5 ebf5da0097f3603204f29b2/limaperan-dan-fungsi-media-sosial-saatpandemi-covid-19-apa-saja-itu?page $=1$

"Tips Orang Tua Dampingi Akses Internet Anak Selama di Rumah”: Medcom.id. Retrieved April 22, 2020 melalui https://www.medcom.id/rona/ keluarga/Wb70xZ6k-tips-orang-tuadampingi-akses-internet-anak-selamadi-rumah 